\title{
Complications of implants confronting the extruded posterior teeth
}

\author{
Yeon-Wook Jung, Su-Yeon Lee, Hee-Jung Kim* \\ Department of Prosthodontics, College of Dentistry, Chosun University, Gwangju, Republic of Korea
}

Purpose: This study investigated the complications and patterns of implants that confronted with the extruded natural teeth. Materials and Methods: Among patients who received implant treatment between 2006 and 2018 at Chosun University Dental Hospital, only implants that had a maintenance period of at least 5 years and that both implants and confronting natural teeth could be measured and compared on a radiograph were selected. They were divided into two groups. Group 1, experimental group consisted of Implants confronting the extruded natural posterior teeth $\left(n=167\right.$ : maxilla (Group $\left.1_{\max }\right)=92$, mandible $\left(G\right.$ roup $\left.\left.1_{\text {man }}\right)=75\right)$ and Group 2, control group consisted of Implants confronting the normal natural posterior teeth $(n=656$ : $\operatorname{maxilla}(G r o u p ~ 2$ max $)=272$, mandible (Group $2_{\text {man }}$ ) = 384). Results: The incidence of complications between Group 1 and Group 2 was statistically significant. In particular, there was a statistically significant difference between the frequency of marginal bone loss and the amount of marginal bone loss. Conclusion: The extruded natural tooth may cause more frequent complications including bone resorption in the opposing implant. (J Dent Rehabil Appl Sci 2020;36(4):232-41)

Key words: extruded; complication; marginal bone loss; implant

\begin{abstract}
서론
임플란트를 이용하여 치아 결손을 치료하는 것은 효과 적이면서도 예지성 있는 치료로 인정받고 있다. ${ }^{1-5}$ 하지만, 임플란트가 보편적 치료로 증가함에 따라 임플란트의 합 병증 또한 지속적으로 보고되고 있다. ${ }^{6,7}$ 임플란트와 관련 하여 임플란트 상실, 임플란트 주위 골 흡수와 임플란트 주위염을 비롯한 임플란트 보철물이나 지대주 나사파절 그리고 임플란트 보철물 탈락 같은 기계적, 생물학적 또 는 기술적 합병증이 다양하게 보고되고 있다. ${ }^{8} \mathrm{Jemt}^{11}$ 은 15 년의 동안 $59.6 \%$ 의 지대주 나사나 지대주의 풀림을 보고하였다. 최근에는 임플란트 구성성분의 디자인 및 제조기술의 발달로 지대주 나사의 풀림이나 많이 감소 하였으나 여전히 $5.8 \%$ 정도의 지대주 나사 풀림이 보고 되었다. ${ }^{12}$ 이와 더불어 가장 흔한 보철관련 합병증은 보
\end{abstract}

*Correspondence to: Hee-Jung Kim

Professor, Department of Prosthodontics, College of Dentistry, Chosun University, 309, Pilmun-daero, Dong-gu, Gwangju, 61452, Republic of Korea

Tel: +82-62-220-3829, Fax: +82-62-232-7776, E-mail: khjdds@chosun.ac.kr

Received: November 24, 2020/Last Revision: November 28, 2020/Accepted:

November 30, 2020
철물의 탈락현상으로 $5.5 \%$ 정도의 발생율이 보고 ${ }^{7}$ 되었 으며, 세라믹과 금속도재관에서 세라믹 파절이나 치핑은 $3.4 \%$ 로 보고되었다. ${ }^{13}$ 임플란트 식립 후 발생하는 변연 골 소실은 임플란트가 식립되는 여러 조건에 따라 다르 게 보고되지만, 통상적으로 임플란트가 기능압을 받은 1 년 후에 $1.5-2 \mathrm{~mm}$ 이내의 흡수와 이후 연간 $0.2 \mathrm{~mm}$ 이 내의 흡수를 보이면 성공적이라 평가되고 있다. ${ }^{14}$ 변연골 흡수에 관하여 Jung 등은 식립 5년 이후에 변연골 흡수 의 빈도는 3\% - 13\% 정도로 다양하게 나타난다 하였다. 구치부 자연치가 상실되었을 때, 적절한 수복치료나 처 치를 받지 않고 방치되는 경우에는 대합하는 치아가 정 출을 일으키는 경향이 있다. Kiliaridis 등 ${ }^{15}$ 은 대합되지 않 는 치아의 $82 \%$ 에서 정출이 발생한다 보고하였으며, 그 중 $24 \%$ 는 $2 \mathrm{~mm}$ 이상의 정출양을 보인다 하였다. Craddock 등 ${ }^{16}$ 은 2004년 발표한 연구 결과를 통해, 대합치가

CopyrightC 2020 The Korean Academy of Stomatognathic Function and Occlusion. (c) It is identical to Creative Commons Non-Commercial License. 
존재하지 않는 155 개의 치아 상실 부위 중 $83 \%$ 에서 정 출이 나타났고, 정출량은 $0.5 \mathrm{~mm}$ 미만에서 $5.4 \mathrm{~mm}$ 까 지 다양하게 나타났다고 보고하였다. 2007년에는 200명 의 환자를 대상으로 한 연구를 통해, 대합되지 않는 치아 의 약 $92 \%$ 에서 정출이 나타난다고 하였고 정출량은 평 균 $1.68 \mathrm{~mm}$, 최대 $3.99 \mathrm{~mm}$ 까지 나타난 것으로 보고하 였다. ${ }^{17}$ 이러한 구치부의 상실로 인해 발생하는 치아의 위 치변화는 치근 노출, 외상성교합, 연조직외상, 치근이개부 노출, 플라그 침착과 관련된 질환 및 교합에 의한 마모의 가속화나 지연에 영향을 주며 보철물 제작을 위한 공간의 감소로 정출치의 발거나 치료를 동반한 교합평면 변경을 고려해야하는 문제점을 야기한다. ${ }^{16,18} \mathrm{Craddock}$ 등 ${ }^{16,17}$ 은 이러한 정출된 치아들은 하악의 전후방 운동시와 작업측 운동시에 높은 빈도의 교합간섭을 유발하며 이러한 구치 부의 정출과 교합간섭이 일주일만에도 일어날 수 있음을 보고하였다.

$\mathrm{Kim}$ 등 $^{19}$ 은 구치부 자연치의 정출량이 $2 \mathrm{~mm}$ 이내일 경우에는 자연치에 부가적인 처치를 하지 않고 임플란트 수복을 하더라도 임플란트의 예후에는 영향을 미치지 않 았다 하였다. 하지만, 앞서 언급한 것처럼 정출된 치아는 보철공간의 부족과 교합간섭을 유발하고 대합되는 임플 란트에 과하중을 야기할 수 있으며, 이러한 과하중으로 인해 보철물의 파절이나 탈락 및 임플란트 주위골의 흡 수 등 장기적으로 합병증을 유발할 수있다. ${ }^{12}$

지금까지 정출치와 임플란트 보철물의 예후에 관련된 몇몇 연구들이 있었으나, 대합치가 정출되어 있을 때 장 기간의 임플란트의 합병증에 대한 조사는 거의 없었다. 본 연구에서는 조선대학교 치과병원에 내원했던 환자들 을 대상으로 정출된 구치와 대합되는 임플란트의 합병 증에 대해 조사하여 정출된 구치와 임플란트 합병증과의 연관성을 분석하고자 하였다.

\section{연구 재료 및 방법}

2006년 1월부터 2018년 6월 사이에 조선대학교 부속 치과병원에서 임플란트 치료를 받았던 6903명의 환자들 중에서 상악과 하악의 자연 대구치가 정출되어 있고, 대 합치가 임플란트로 수복된 조건을 가진 환자는 983명이 었다. 환자의 차트와 방사선 사진을 이용하여 합병증 분 석 가능한 823 명의 환자를 최종적으로 선택하였다. 선택 된 환자 중 남자는 502명이었고 여자는 321명이었다. 정 출된 구치와 대합되는 부위에 식립된 구치부 임플란트를 실험군(이하 Group 1)으로 하였으며, 정출이 관찰되지 않는 구치부와 대합되는 부위에 식립된 구치부 임플란트 를 대조군(이하 Group 2)으로 하였다. Group 1 선정시 정출된 제 1 대구치나 제 2 대구치와 대합되는 임플란트를 선택하였으며, 인접한 대구치가 두 개 모두 정출시에는 잔존하는 자연치와 인접하는 첫번째 임플란트만을 실험 군으로 선택하였다. Group 1을 이루는 환자는 167명(남 106명, 여 61명)이었고 평균나이는 59.36세였다. Group 1 에는 총 167 개의 임플란트가 선정되었고, 상악(이하 Group $1_{\max }$ )은 92개, 하악(이하 Group $1_{\operatorname{man}}$ )은 75개였다. Group 1 임플란트의 유지관리기간은 평균 8.12년 정도 였다. Group 2는 656명(남 396명, 여 260명)이었으며, 평 균나이는 58.89세였다. 총 656개의 임플란트가 Group 2 로 선정되었으며, 상악(이하 Group $2_{\max }$ )은 272개, 하악 (이하 Group $2_{\operatorname{man}}$ )은 384개였다(Table 1). Group 2에 포 함된 임플란트의 유지관리기간은 평균 8.05년 정도였다.

정출여부를 평가하기 위한 계측 방법으로 파노라마 사 진 및 표준촬영 방사선 사진에서 표준화되지 않은 선형 측정법을 이용하였다. 정출유무를 판단하기 위해 방사 선 사진상에서 전후방 치열의 연속성과 대칭성을 고려하 였고 인접한 소구치나 대구치의 변연융선의 높이 차이가 뚜렷한 경우만을 정출치로 선정하였다. 대상 임플란트를

Table 1. Classification and experimental and control groups

\begin{tabular}{cccccr}
\hline & Sample & Sex & & \multicolumn{2}{c}{ Jaw } \\
& & Male & Female & Maxilla & Mandible \\
\hline Group 1 & 167 & 106 & 61 & 92 & 75 \\
Group 2 & 656 & 396 & 260 & 272 & 384 \\
\hline
\end{tabular}


선정한 후에 내원기록과 파노라마 및 표준촬영 사진을 참고하여 Group 1과 Group 2의 임플란트 합병증 양상 을 조사하였다. 합병증 항목은 보철물이 탈락한 경우, 보 철물 파절된 경우, 임플란트 주변 치조골이 소실된 경우 로 나누어 조사하였다. 보철물의 파절이나 탈락은 차트 의 기록을 기반으로 빈도를 조사하였다. 보철물 파절에 는 세라믹이나 금속도재관의 포세라인 파절 및 보철물의 천공을 포함하였으며, 보철물의 탈락은 시멘트의 상실과 더불어 지대주 나사의 풀림과 지대주 나사의 파절로 인 한 보철물 탈락을 포함하였다. 자연치의 정출량은 대합 되는 임플란트의 침하량으로 측정하였으며, 방사선 사진 프로그램(INFINITT PACS)상에서 치근단 방사선사진 을 이용하여 측정하였다. 임플란트 길이의 비율을 이용 하여 인접자연치의 변연융선으로부터 임플란트 보철의 침하량을 기록하였다. 그리고, 임플란트 변연골 흡수에 대한 측정은 표준 촬영사진 상에서 임플란트의 길이의 비율을 이용하여 변연골 소실 길이로 측정하였다. 선정된 표본 임플란트를 대상으로 조사가 진행되었으며, 합병증 발생 빈도에 유의한 차이가 있는지 조사하였고 또한 정 출유무에 따라 합병증의 세부 항목별로 유의한 차이가 있는지 조사하였다. 또한, 각 그룹 간의 상악과 하악에 서 발생하는 합병증에 대해서도 분석하였다.

모든 통계는 IBM SPSS 25v (SPSS for windows, SPSS INC, Chicago, USA) 프로그램을 사용하여 처리하였다. 합병증 발생빈도 분석시에는 Pearson chi-squared test를 이용하였고 합병증 세부항목 분석시에는 Pearson chisquared test와 Fisher's exact test를 사용하였다. 또한 변연골 소실에서 상악, 하악 그룹간 평균 소실양 비교시 Mann-whitney U test 사용하였으며 군간 통계적 유의성 판정을 위한 유의수준은 5\%로 설정하여 유의성을 평가 하였다.

\section{결과}

Group 1의 치근단 방사선 사진 상에서 측정된 임플란 트 침하량(이하 자연치의 정출량)의 평균치는 약 $1.67 \pm$ $0.78 \mathrm{~mm}$ 였다

이 연구에서 나타난 합병증의 발생양상은 다음과 같았 다. Group 1에서 보철물의 탈락, 보철물의 파절 및 임플 란트 주위 치조골 흡수를 보인 임플란트는 57개였으며, 보철물 탈락(loss of retention)이 9개, 보철물 파절이 1 개, 변연골 소실이 47 개로 나타났다. 합병증이 발생한 비 율은 $34.13 \%$ 였으며, 보철물 탈락은 $5.39 \%$, 보철물 파절 은 $0.60 \%$, 변연골 소실은 $28.14 \%$ 를 차지하였다. Group 1 합병증 중에서는 변연골 소실이 가장 많은 빈도로 나 타났다(Table 2).

Group 2에서는 138 개의 임플란트에서 139 개의 합병 증 $(21.19 \%)$ 이 나타났으며, 보철물 탈락이 26개(3.96\%), 보철물 파절이 12 개(1.83\%), 치조골 흡수는 101 개 $(15.40 \%)$ 로 나타났다(Table 1). Group 2 에서도 치조골 흡수가 가장 많은 합병증으로 나타났다. Group $2_{\operatorname{man}}$ 중 1 개의 임플란트에서 보철물 탈락과 치조골 소실이 같이 발생하였다. 합병증의 전반적인 발생빈도는 Group 1과 Group 2이 각각 $34.13 \%, 21.19 \%$ 로 통계학적 유의한 차 이를 보였다 $(P<0.05$, Fig. 1$)$.

조사한 합병증 세부항목 중 보철물 탈락(Pearson chisquared test, $P>0.05)$ 과 보철물 파절(Fisher exact test, $P>0.05)$ 빈도는 Group 1과 Group 2 사이에 통계학적 유의성은 없었다. 하지만, 치조골 소실의 빈도는 두 그룹 사이에 통계학적 유의성이 존재하였다 $(P<0.05$, Table 1, Fig. 2).

실험군인 Group 1의 상악 (Group $1_{\max }$ )과 대조군인 Group 2의 상악만(Group $2_{\max }$ )을 통계학적으로 비교하

Table 2. Incidence rate of implant complications in this study

$(\%(\mathrm{n}))$

\begin{tabular}{lcccccc}
\hline Complication & $\begin{array}{c}\text { Group 1 } \\
(\mathrm{n}=167)\end{array}$ & $\begin{array}{c}\text { Group 1 } \\
(\mathrm{n}=92)\end{array}$ & $\begin{array}{c}\text { Group 1 } 1_{\operatorname{man}} \\
(\mathrm{n}=75)\end{array}$ & $\begin{array}{c}\text { Group 2 } \\
(\mathrm{n}=656)\end{array}$ & $\begin{array}{c}\text { Group 2 } \\
(\mathrm{n}=272)\end{array}$ & $\begin{array}{c}\text { Group 2 } \\
(\mathrm{n}=384)\end{array}$ \\
\hline Loss of retention & $5.39(9)$ & $2.99(5)$ & $2.40(4)$ & $3.96(26)$ & $1.52(10)$ & $2.44(16)$ \\
Prosthesis fracture & $0.6(1)$ & $0.60(1)$ & $0(0)$ & $1.83(12)$ & $0.91(6)$ & $0.91(6)$ \\
Marginal bone loss & $28.14(47)$ & $16.17(27)$ & $11.98(20)$ & $15.40(101)$ & $6.25(41)$ & $9.15(60)$ \\
Total & $34.13(57)$ & $19.76(33)$ & $14.38(24)$ & $21.19(139)$ & $8.69(57)$ & $12.50(82)$ \\
\hline
\end{tabular}




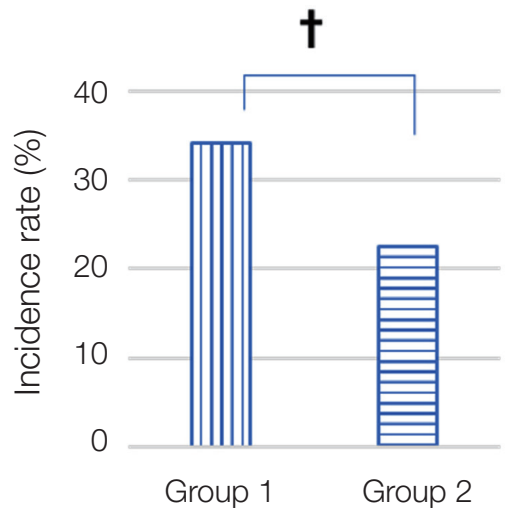

Fig. 1. Incidence rate of complications. Pearson chi-squared test, $+: P<0.05$.

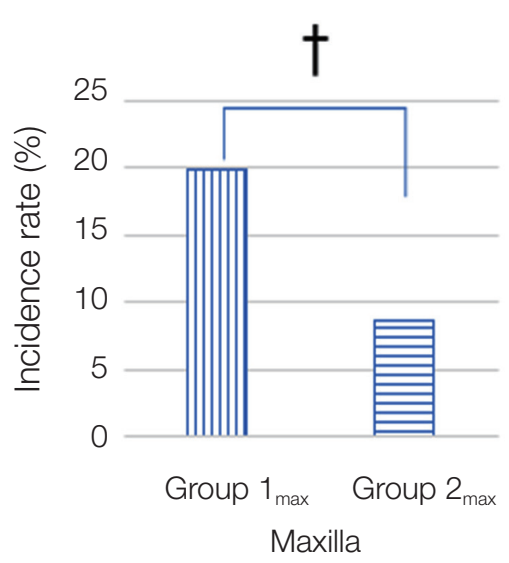

Fig. 3. Incidence rate of complications in maxilla. Pearson chi-squared test, + : $P<$ 0.05 .

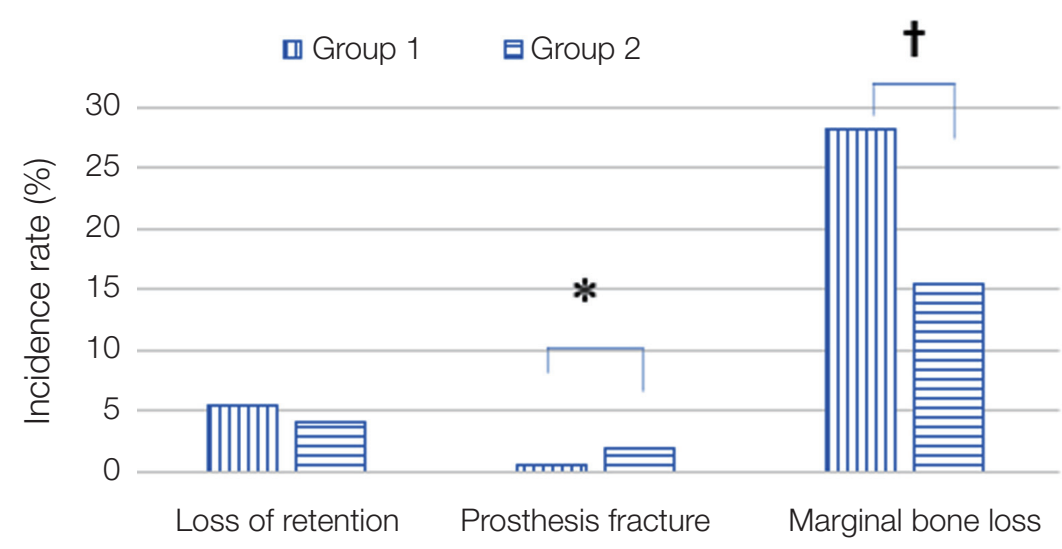

Fig. 2. Incidence rate of each complication. Pearson chi-squared test, $+: P<$ 0.05 , Fisher exact test, $*$; $P>0.05$.

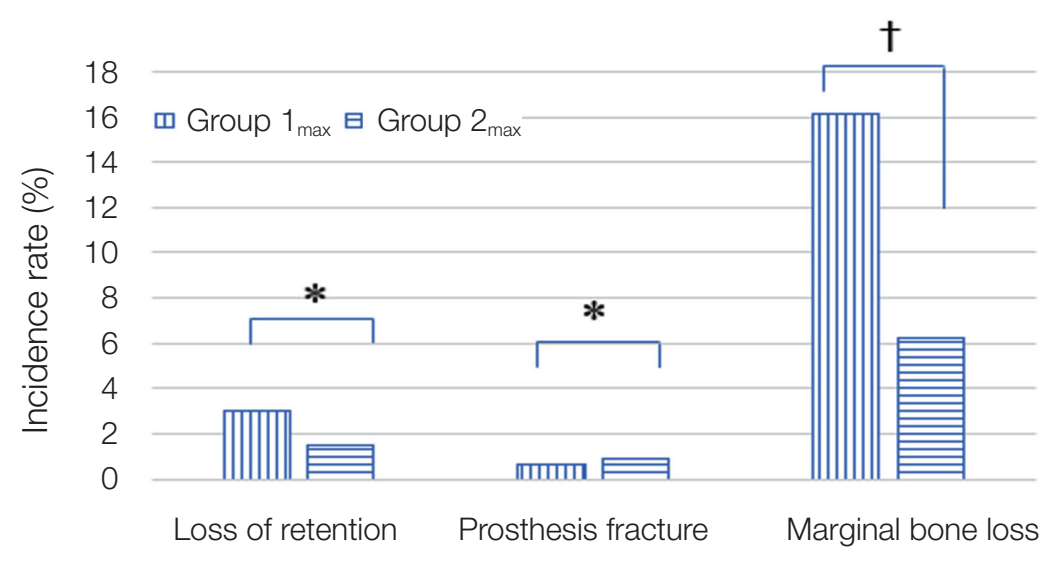

Fig. 4. Incidence rate of each complication in maxilla. Pearson chi-squared test, $+: P<0.05$, Fisher exact test, $*: P>0.05$.
였더니, 두 그룹사이에 전체적인 합병증 발생빈도는 통 계학적으로 유의성을 보였다 $(P<0.05$, Fig. 3). 합병증의 세부항목 중에서 보철물 탈락과 보철물 파절에는 통계학 적 유의성을 보이지 않았으나, 치조골 소실빈도에는 통 계학적으로 유의한 차이가 있었다 $(P<0.05$, Fig. 4).

두 그룹의 하악 임플란트만을 비교하였더니, Group $1_{\operatorname{man}}$ 과 Group $2_{\operatorname{man}}$ 사이에 전체적인 합병증발생 빈도뿐 만 아니라 세부 합병증 항목인 보철물 탈락, 보철물 파절 및 치조골 소실빈도 모두에서 통계학적 유의성이 존재하 지 않았다 $(P>0.05$, Fig. 5, Fig. 6).

방사선 사진상에서 측정된 Group 1의 전체 변연골 평 균 소실양 $0.67 \pm 1.26 \mathrm{~mm}$, Group 2 는 $0.32 \pm 0.91 \mathrm{~mm}$
였으며, 두 그룹 간에 통계학적 유의성이 존재하였다 (Mann-whitney U test, $P<0.05$, Fig. 7). 상악의 변연골 흡수는 Group $1_{\max }$ 와 Group $2_{\max }$ 에서 각기 평균 $0.71 \pm$ $1.31 \mathrm{~mm}, 0.34 \pm 0.94 \mathrm{~mm}$ 였으며, 두 그룹사이에 통계 학적 유의성이 존재하였다(Mann-whitney U test, $P<$ 0.05, Fig. 8). 하악의 변연골 흡수는 Group $1_{\operatorname{man}}$ 과 Group $2_{\operatorname{man}}$ 에서 각기 $0.62 \pm 1.20 \mathrm{~mm}, 0.31 \pm 0.89 \mathrm{~mm}$ 였으며, 두 그룹사이에도 역시 통계학적 유의성이 존재하였다 (Mann-whitney U test, $P<0.05$, Fig. 8, Table 3).

Group 1과 Group 2 임플란트 중에서 변연골 흡수를 나타내는 임플란트들만의 평균 흡수량을 조사였더니, 각 기 $2.38 \pm 1.25 \mathrm{~mm}, 2.09 \pm 1.31 \mathrm{~mm}$ 였으며, 통계학적으 


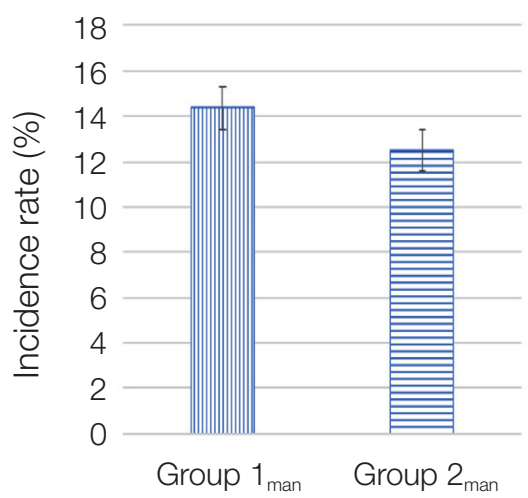

Fig. 5. Incidence rate of complications in mandible. Pearson chi-squared test, $P>$ 0.05 .

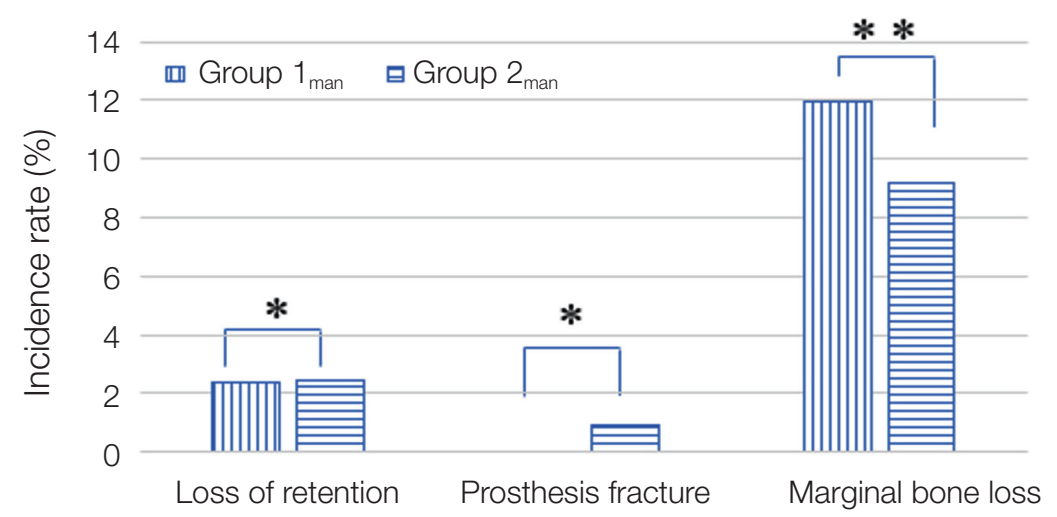

Fig. 6. Incidence rate of each complication in mandible. Fisher exact test, *: $P>0.05$, Pearson chi-squared test, ${ }^{* *}: P>0.05$.

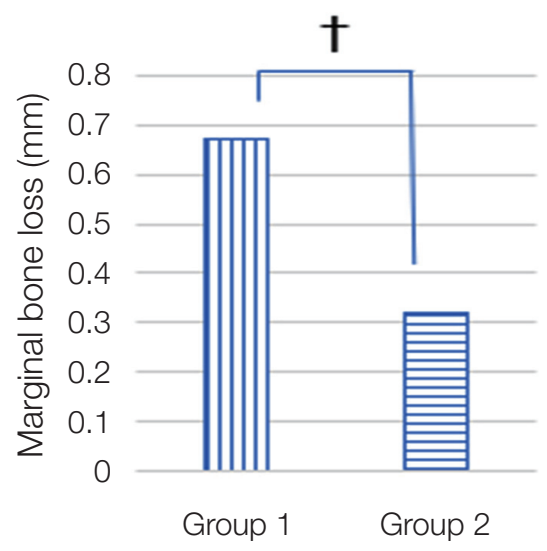

Fig. 7. Mean marginal bone loss. Mannwhitney $U$ test, + : $P<0.05$.

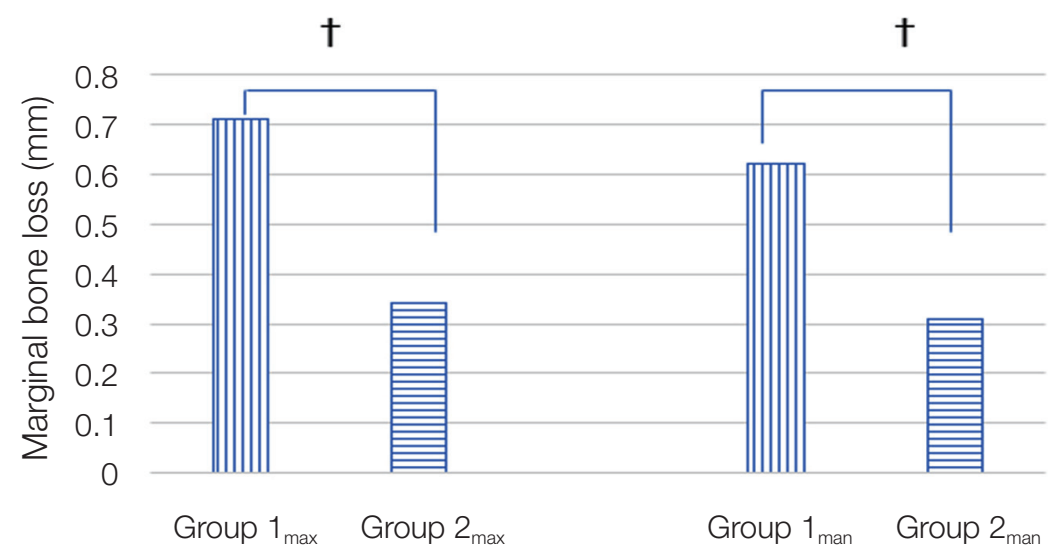

Fig. 8. Mean marginal bone loss in maxilla and mandible. Mann-whitney $U$ test, $\dagger ; P<0.05$.
Table 3. Amount of mean marginal bone loss in each group

\begin{tabular}{lcc}
\hline & $\begin{array}{c}\text { Mean marginal } \\
\text { bone loss }\end{array}$ & $\begin{array}{c}\text { Number of } \\
\text { sample }\end{array}$ \\
\hline Group 1 & $0.67 \pm 1.26 \mathrm{~mm}^{\mathrm{a}}$ & 167 \\
Group 1 & $0.71 \pm 1.31 \mathrm{~mm}_{\max }^{\mathrm{b}}$ & 92 \\
Group 1 & $0.62 \pm 1.20 \mathrm{~mm}_{\operatorname{man}}^{\mathrm{c}}$ & 75 \\
Group 2 & $0.32 \pm 0.91 \mathrm{~mm}^{\mathrm{a}}$ & 656 \\
Group 2 & $0.34 \pm 0.94 \mathrm{~mm}_{\max }^{\mathrm{b}}$ & 272 \\
Group 2 & $0.31 \pm 0.89 \mathrm{~mm}_{\operatorname{man}}^{\mathrm{c}}$ & 384 \\
\hline
\end{tabular}

Data were presented as mean \pm standard deviation.

Same letter $\left(a,{ }^{\mathrm{b}},{ }^{\circ}\right)$ denoted a statistically significant difference.

Mann-whitney $\mathrm{U}$ test, ${ }^{\mathrm{a}},{ }^{\mathrm{b}},{ }^{\mathrm{c}}: P<0.05$.
로 비교시 변연골의 흡수를 보인 임플란트들의 그룹간 평균 흡수량은 통계적으로 유의한 차이가 없었다(Mannwhitney $\mathrm{U}$ test, $P>0.05$, Fig. 9, Table 4).

상악과 하악에 따라 흡수량의 차이를 각기 비교하였더 니, 정출된 Group $1_{\max }$ 와 Group $1_{\operatorname{man}}$ 의 평균값이 $2.40 \pm$ $1.33 \mathrm{~mm}, 2.34 \pm 1.17 \mathrm{~mm}$ 로 Group $2_{\max }$ 와 Group $2_{\operatorname{man}}$ 의 흡수량보다 높게 나왔지만, 통계학적으로 유의성은 발견되지 않았다(Mann-whitney U test, $P>0.05$, Table 4, Fig. 9, Fig. 10). 


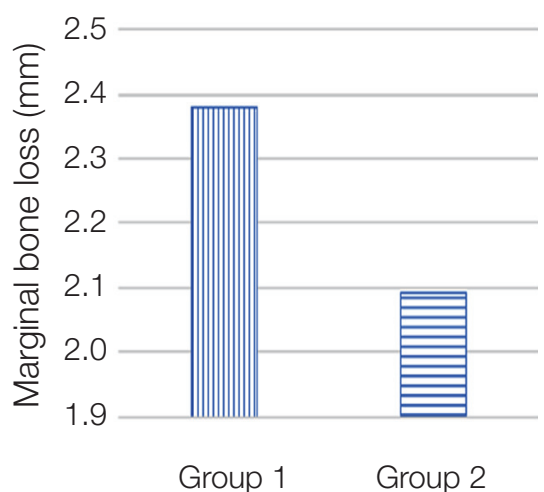

Fig. 9. Mean marginal bone loss of only implants with bone loss. Mann-whitney U test, $P>0.05$.

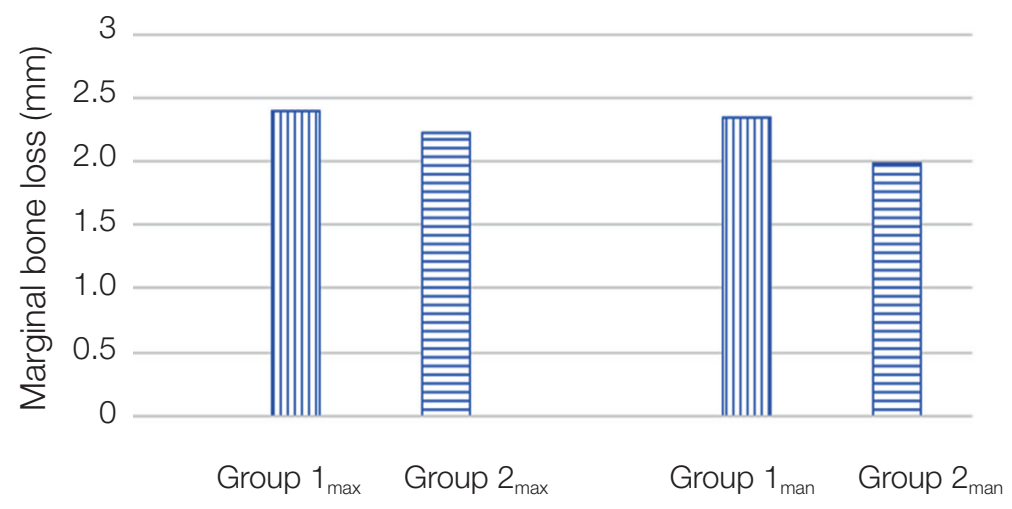

Fig. 10. Mean marginal bone loss of only implants with bone loss in maxilla and mandible. Mann-whitney $U$ test, $P>0.05$.
Table 4. Amount of mean marginal bone loss in implants with bone loss

\begin{tabular}{lcc}
\hline & $\begin{array}{c}\text { Mean marginal } \\
\text { bone loss }\end{array}$ & $\begin{array}{c}\text { Number of } \\
\text { sample }\end{array}$ \\
\hline Group 1 & $2.38 \pm 1.25 \mathrm{~mm}$ & 47 \\
Group 1 & $2.40 \pm 1.33 \mathrm{~mm}$ & 27 \\
Group 1 & $2.34 \pm 1.17 \mathrm{~mm}$ & 20 \\
Group 2 & $2.09 \pm 1.31 \mathrm{~mm}$ & 101 \\
Group 2 & $2.22 \pm 1.30 \mathrm{~mm}$ & 41 \\
Group 2 & $1.99 \pm 1.33 \mathrm{~mm}$ & 60 \\
\hline
\end{tabular}

\section{고찰}

임플란트는 다양한 치아 결손 부위의 수복을 위한 안 정성과 예지성이 높은 치료이지만, 임플란트 보철과 임 플란트 주위 조직에 합병증이나 실패 양상들이 지속적으 로 발생하고 있으므로 임플란트 치료를 위한 진단을 할 때에는 실패 및 위험인자에 대한 평가가 필요하다. ${ }^{6-8,20}$ 이 연구는 정출된 자연치가 대합되는 임플란트에 어떠한 영 향을 미치는 지에 대해 고찰하고자 하였다. 차트상의 진 료 기록과 방사선 사진상의 계측을 통하여 고찰을 시행 하였으며, 차트기록이 불분명하거나 방사선 사진이 누락 되거나 뚜렷하지 않는 것은 제외하였다. 정출유무는 방 사선 사진상에서 전후방 치열의 연속성과 대칭성을 고려 하여 인접한 자연치의 변연융선과 높이차이가 뚜렷한 경 우만 정출로 선정되었다. 정출량은 치근단 방사선사진의 확대율을 이용해 대합되는 임플란트의 침하량으로 측정
하였다. 983 명의 환자에서 분석 및 측정이 가능한 환자는 823명이었으며, 정출된 구치와 대합되는 부위에 임플란 트를 식립하는 경우가 통상적인 경우 보다 빈도가 적어 실험군이 167 명, 대조군이 656 명으로 선정되었다.

Group 1의 임플란트와 대합되는 자연치의 평균 정출 양은 약 $1.67 \pm 0.78 \mathrm{~mm}$ 였다. 이 정출양은 방사선사진 상의 확대율만을 이용해 측정했기 때문에 연구의 결과로 채택하지 않았다. 하지만, Craddock 등 ${ }^{17}$ 이 성인에서 구 치부 상실 후 평균 $1.68( \pm 0.79) \mathrm{mm}$ 의 대합치 정출이 발 생하였다는 보고를 고려해보면 본 연구의 방사선사진을 이용한 분석의 오차가 허용할 만한 수준이었을 것으로 사료된다.

이 연구에서 Group 1과 Group 2에서 발생되는 합병 증의 발생율은 각각 $34.13 \%, 21.19 \%$ 로 Group 1에서 합 병증이 통계학적으로 유의성 있게 빈번하게 발생하였다. 즉, 전반적인 합병증 발생빈도는 정출된 구치와 대합되 는 임플란트에서 더 많았음 알 수 있다. 하지만, 합병증의 항목에서 보철물의 탈락과 보철물의 파절은 두 그룹사이 (Group 1과 Group 2)에서 뿐만 아니라, 두 그룹의 상악 간(Group $1_{\max }$ 와 Group $2_{\max }$ ) 비교와 하악간(Group $1_{\operatorname{man}}$ 와 Group $2_{\operatorname{man}}$ )비교에서도 차이를 보이지 않았다.

변연골 소실의 빈도는 Group 1에서 Group 2 보다 유 의성 있게 높게 나타났다. 두 그룹의 상악간(Group $1_{\max }$ 와 Group $2_{\max }$ )의 골소실 빈도를 비교하였더니, Group $1_{\max }$ 가 Group $2_{\max }$ 보다 유의성 있는 변연골 소실율 을 나타내었다. 반면에, Group $1_{\operatorname{man}}(11.98 \%)$ 와 Group $2_{\operatorname{man}}(9.15 \%)$ 사이에서는 Group $1_{\operatorname{man}}$ 의 변연골 소실 빈도 
가 이 수치적으로는 높으나 통계학적으로 유의성이 발견 되지 않았다. 이의 결과를 고려해 볼 때, 정출된 구치가 대 합하는 임플란트에 합병증을 더욱 빈번하게 유발시켰으 며, 그 합병증 중에서도 대합하는 임플란트의 변연골의 흡수를 가장 빈번하게 발생시킨다고 할 수 있다. 또한, 정 출된 자연치가 하악 대구치인 경우가 상악 대구치인 경우 보다 대합하는 임플란트의 변연골 흡수를 더 높은 빈도 로 야기한다고 할 수 있다. 이러한 현상은 자연치가 정출 시 발생하는 교합간섭과 외상성 교합 및 플라그 침착과 관련된 것으로 추정해 볼 수 있다. Hirschfield 등 $^{18}$ 은 구 치의 상실로 인해 발생하는 치아의 위치변화가 외상성교 합, 치근노출, 연조직외상, 치근이개부 노출, 플라그 침착 과 관련된 질환 및 교합에 의한 마모의 속도에 영향을 준 다고 하였다. 또한, Craddock 등 ${ }^{16,17}$ 은 정출이 일어나 자 연치는 작업측 교합간섭과 전방운동시 교합간섭을 야기 하며, 구치부 정출은 교합간섭 뿐만 아니라 보철제작을 위한 공간을 감소시킨다 하였다. 이 실험의 결과와 문헌 고찰을 고려할 때, 정출된 구치와 대합되는 임플란트의 합병증의 발생이 더욱 많이 발생한 것은 정출된 자연치 로 인한 외상성 교합이나 교합간섭에 의한 것으로 사료 된다.

그룹간 변연골 평균 흡수량에서도 Group 1 (0.67 \pm $1.26 \mathrm{~mm})$ 이 Group 2 (0.32 $\pm 0.91 \mathrm{~mm})$ 에 비해 유의하 게 높게 나타났다. Group 1 의 임플란트의 변연골 흡수 량이 Group 2의 임플란트에 비해 두 배이며 통계적으로 유의성을 보였다. 그리고, 두 그룹 사이의 상악간(Group $1_{\max }$ 와 Group $2_{\max }$ )과 하악간(Group $1_{\operatorname{man}}$ 와 Group $2_{\operatorname{man}}$ ) 의 비교에서도 역시 상하악 모두 Group 1에서 통계적으 로 유의한 골흡수량을 보였다. 이러한 결과를 고려할 때, 정출된 자연치가 대합되는 임플란트의 변연골 흡수에 영 향을 주었을 것으로 추정된다. 기존에 보고된 변연골 흡 수량은 임플란트 식립조건과 시스템 및 유지관찰기간이 통일되지 않아 고찰마다 결과가 매우 다양하다. 약 5년 이상의 장기간의 연구결과에서 변연골 흡수는 $0.04 \mathrm{~mm}$ - $2.12 \mathrm{~mm}$ 까지 보고되었다. ${ }^{21,22} \mathrm{Jung}$ 등 $^{7}$ 은 메타분석을 통해 임플란트 식립 5년 후 변연골 소실의 빈도는 3\% $13 \%$ 로 다양한 빈도로 발생하였으며, $2 \mathrm{~mm}$ 이상의 골흡 수를 보이는 것은 $6.3 \%$ 라 하였다. 본 연구에서는 Group 2 의 골흡수 빈도가 $15.40 \%$ 로 Jung 등의 연구에 비해 다 소 높게 나타났다. 이것은 본 연구의 임플란트 평균 유지 기간이 8.05년으로 더 길었기 때문이라 사료된다. Group 1 과 Group 2의 평균 골 흡수량은 각각 $0.67 \mathrm{~mm}, 0.32$ $\mathrm{mm}$ 였으며, 두 그룹 사이에 유의한 차이가 있었다. 하 지만, 각 그룹의 평균 골 흡수량 모두 기존 연구에서 보 고된 고찰의 범위내에 있었다. 특히, 대조군이 Group 2 의 흡수량은 기존의 연구와 매우 유사한 결과를 나타내 었다. 한편, $\mathrm{Kim}$ 등 $^{19}$ 은 정출된 자연치와 대합되는 33 개 의 임플란트의 임상적 예후를 약 2.5 년 간 관찰하였는데, 변연골 소실양이 $0.09 \pm 0.30 \mathrm{~mm}$ 이고 보철적 합병증은 $3.03 \%$ 였다고 하였다. 보철적 합병증의 빈도에서는 본 연 구 결과 $(5.39 \%)$ 와 큰 차이를 보이지 않았으나, 변연골 흡 수량은 상당한 차이를 보였다. 이는 본 연구에서 고찰된 임플란트의 유지관리 기간이 평균 8.12년으로 $\mathrm{Kim}^{\text {등 }}{ }^{19}$ 의 유지관리 기간보다 길었으며, 표본의 수도 많았기 때 문인 것으로 사료된다.

그룹의 평균 변연골 흡수와는 달리 골흡수가 일어난 임플란트(Group 1은 47개, Group 2는 101개)만의 평균 흡수량을 비교하였더니, Group 1 (2.38 $\pm 1.25 \mathrm{~mm})$ 이 Group $2(2.09 \pm 1.31 \mathrm{~mm})$ 보다 수치적으로는 높은 평 균 흡수량을 나타냈으나, 통계학적으로는 유의성이 존재 하지 않았다. 이러한 결과는 두 그룹 사이에 상악간 또는 하악간 비교에서도 같은 경향을 나타내었다. 비록 통계 학적으로 유의성은 없었으나, 일단 흡수가 일어난 임플 란트들 간에도 역시 정출된 구치와 대합되는 임플란트가 수치상으로는 더욱 많은 흡수량을 보여주었다.

이 연구에서 한계점은 실험군과 대조군 두 그룹에서 임플란트들의 평균 변연골 흡수량을 측정하였으나, 내측 연결형 임플란트와 외측연결형 임플란트를 구분하여 비 교하지 못하였다는 것이고, 이는 추가적인 연구가 필요 하다. 연구결과 정출된 자연치와 대합되는 부위에 식립된 임플란트가 통상적인 임플란트에 비해 더욱 빈번한 합병 증을 보였으며, 특히 통계학적으로 유의할 정도로 많은 골소실 빈도와 골흡수량를 보였다. 특히, 골흡수 빈도는 상악의 임플란트에서 통계학적으로 유의성을 보였으나 하악에서는 유의성이 발견되지 않았다. 즉, 정출된 하악 대구치에 대합되는 상악 구치부 임플란트가 더욱 많은 빈도의 골소실율을 보였다

\section{결론}

이 연구는 대합하는 자연치의 정출 유무가 임플란트 의 합병증에 미치는 영향에 대해 고찰하고자 하였다. 이 연구의 결과 내에서 정출된 구치가 대합되는 임플란트에 그렇지 않은 경우보다 더 높은 골소실 빈도와 많은 변연 
골 흡수량을 나타내었다. 이러한 골소실의 빈도는 상악 임플란트에서 더욱 뚜렷하였다. 따라서, 임플란트 치료 를 할 때, 대합되는 부위의 구치부 자연치가 정출된 경우 에는 정출된 구치부에 대한 수정 및 치료를 고려하는 것 이 추천된다.

\section{Acknowledgements}

이 논문은 2017년 조선대학교 학술연구비의 지원을 받 아 연구되었음.

\section{ORCID}

Yeon-Wook Jung https://orcid.org/0000-0003-0123-1006 Su-Yeon Lee https://orcid.org/0000-0001-7035-1082

Hee-Jung Kim https://orcid.org/0000-0002-2015-1530

\section{References}

1. Berglundh T, Persson L, Klinge B. A systematic review of the incidence of biological and technical complications in implant dentistry reported in prospective longitudinal studies of at least 5 years. J Clin Periodontol 2002;29 Suppl 3:197-212.

2. Bornstein MM, Halbritter S, Harnisch H, Weber HP, Buser D. A retrospective analysis of patients referred for implant placement to a specialty clinic: indications, surgical procedures, and early failures. Int J Oral Maxillofac Implants 2008;23:1109-16.

3. Karoussis IK, Müller S, Salvi GE, Heitz-Mayfield LJ, Brägger U, Lang NP. Association between periodontal and peri-implant conditions: a 10-year prospective study. Clin Oral Implants Res 2004;15:1-7.

4. Karoussis IK, Kotsovilis S, Fourmousis I. A comprehensive and critical review of dental implant prognosis in periodontally compromised partially edentulous patients. Clin Oral Implants Res 2007;18:669-79.

5. Lang NP, Pjetursson BE, Tan K, Brägger U, Egger $\mathrm{M}$, Zwahlen M. A systematic review of the survival and complication rates of fixed partial dentures (FPDs) after an observation period of at least 5 years. II. Combined tooth-implant-supported FPDs. Clin Oral Implants Res 2004;15:643-53.
6. Goodacre CJ, Bernal G, Rungcharassaeng K, Kan JY. Clinical complications with implants and implant prostheses. J Prosthet Dent 2003;90:121-32.

7. Jung RE, Pjetursson BE, Glauser R, Zembic A, Zwahlen M, Lang NP. A systematic review of the 5 -year survival and complication rates of implantsupported single crowns. Clin Oral Implants Res 2008;19:119-30.

8. Hanif A, Qureshi S, Sheikh Z, Rashid H. Complications in implant dentistry. Eur J Dent 2017;11:13540.

9. Henry PJ, Laney WR, Jemt T, Harris D, Krogh PH, Polizzi G, Zarb GA, Herrmann I. Osseointegrated implants for single-tooth replacement: a prospective 5-year multicenter study. Int J Oral Maxillofac Implants 1996;11:450-5.

10. Taylor RC, McGlumphy EA, Tatakis DN, Beck FM. Radiographic and clinical evaluation of singletooth Biolok implants: a 5-year study. Int J Oral Maxillofac Implants 2004;19:849-54.

11. Jemt T. Single implants in the anterior maxilla after 15 years of follow-up: comparison with central implants in the edentulous maxilla. Int J Prosthodont 2008;21:400-8.

12. Pjetursson BE, Asgeirsson AG, Zwahlen M, Sailer I. Improvements in implant dentistry over the last decade: comparison of survival and complication rates in older and newer publications. Int J Oral Maxillofac Implants 2014;29 suppl:308-24.

13. Sadid-Zadeh R, Kutkut A, Kim H. Prosthetic failure in implant dentistry. Dent Clin North Am 2015;59:195-214.

14. Galindo-Moreno P, León-Cano A, Ortega-Oller I, Monje A, Valle FO, Catena A. Marginal bone loss as success criterion in implant dentistry: beyond 2 mm. Clin Oral Implants Res 2015;26:e28-34.

15. Kiliaridis S, Lyka I, Friede H, Carlsson GE, Ahlqwist M. Vertical position, rotation, and tipping of molars without antagonists. Int J Prosthodont 2000;13:480-6.

16. Craddock HL, Youngson CC. A study of the incidence of overeruption and occlusal interferences in unopposed posterior teeth. Br Dent J 2004;196: 341-8.

17. Craddock HL, Youngson CC, Manogue M, Blance 
A. Occlusal changes following posterior tooth loss in adults. Part 1: a study of clinical parameters associated with the extent and type of supra-eruption in unopposed posterior teeth. J Prosthodont 2007;16: 485-94.

18. Hirschfeld I. The individual missing tooth: a factor in dental and periodontal disease. J Am Dent Assoc 1937;24:67-82.

19. Kim YK, Ahn KJ, Yun PY, Yi YJ, Kim SG. The clinical prognosis of implants that are placed against super-erupted opposing dentition. J Korean Assoc Oral Maxillofac Surg 2016;42:139-43.

20. Han HJ. Evaluation of implant failure causes: a 19Year retrospective study. PhD Thesis; The Graduate School, Yonsei University, 2010.

21. Garaicoa-Pazmiño C, Suárez-López del Amo F, Monje A, Catena A, Ortega-Oller I, GalindoMoreno P, Wang HL. Influence of crown/implant ratio on marginal bone loss: a systematic review. 2014;85:1214-21.

22. Monje A, Suarez F, Galindo-Moreno P, GarcíaNogales A, Fu JH, Wang HL. A systematic review on marginal bone loss around short dental implants $(<10 \mathrm{~mm})$ for implant-supported fixed prostheses. Clin Oral Implants Res 2014;25:1119-24. 


\section{정출된 구치와 대합되는 임플란트의 합병증}

정연욱 대학원생, 이수연 대학원생, 김희중* 교수

조선대학교 치과대학 치과보철학교실

목적: 이 연구는 정출된 자연치와 대합되는 임플란트에 발생하는 합병증과 그 양상에 대해 고찰하여 대합치 정출이 임플 란트 합병증에 어떠한 영향을 미치는지에 대해 알아보고자 하였다.

연구 재료 및 방법: 조선대학교 치과병원에서 2006년부터 2018년 사이에 임플란트치료를 받은 환자 중에서 유지관리기 간이 최소 5 년 이상이면서 구치부 임플란트와 대합되는 자연치가 방사선 사진상으로 측정 및 비교 가능한 임플란트만 을 선택하였다. 정출된 구치부 자연치와 대합되는 임플란트를 실험군인 Group 1 ( $\mathrm{n}=167$ : 상악 $\left(\mathrm{Group} 1_{\max }\right)=92$, 하악 (Group $\left.1_{\operatorname{man}}\right)=75$ )과 정출소견이 없는 구치부 자연치와 대합되는 임플란트를 대조군인 Group 2 ( $\mathrm{n}=656$ : 상악(Group $\left.1_{\max }\right)=272$, 하악 $\left.\left(G \operatorname{roup} 1_{\operatorname{man}}\right)=384\right)$ 로 분류하였다. 두 그룹 사이에 합병증의 발생빈도와 변연골 흡수에 대해 조사하였다.

결과: Group 1과 Group 2 사이에 합병증의 발생빈도는 통계학적으로 유의성이 있었다. 특히, 상악골의 치조골 소실 빈 도와 치조골 소실 양이 통계적으로 유의한 차이를 나타내었다.

결론: 정출된 자연치는 대합되는 임플란트에 골흡수를 비롯한 합병증을 더 빈번하게 유발할 수 있다.

(구강회복응용과학지 2020;36 (4):232-41)

주요어: 정출; 합병증; 변연골 흡수; 임플란트

*교신저자: 김희중

(61452) 광주광역시 동구 필문대로 309 조선대학교 치과대학 치과보철학교실

Tel: 062-220-3829 | Fax: 062-232-7776 | E-mail: khjdds@chosun.ac. kr

접수일: 2020년 11월 24일 | 수정일: 2020년 11월 28일 | 채택일: 2020년 11월 30일 